Journal of Chemical Engineering, IEB

Vol. ChE. 26, No. 1, December 2011

\title{
PROSPECTS AND CHALLENGES OF PLASTIC INDUSTRIES IN BANGLADESH
}

\author{
M. Serajul Islam \\ Former Associate Professor of Chemical Engineering, BUET, Dhaka
}

\begin{abstract}
Plastic is an engineered material used to manufacture a wide variety of products to meet the domestic demand in Bangladesh as well as some products are exported. The plastic industry has emerged as an important industrial sector in the country during the last two decades. At present there are 3000 plastic manufacturing units, 98\% of which belong to the Small-Medium Enterprises (SMEs). Domestic market size is Tk 7,000 crore. Per capita consumption of plastics in Bangladesh is $5 \mathrm{~kg}$ per year. The plastic sector constitutes 1.0 of GDP and provides employment for half a million people. Total export earning for both direct and deem (RMG accessories) exports is about US $\$ 337$ million.

An in-depth study of the plastic sector reveals multi-dimensional constraints and an excellent prospect for future growth. Major constraint in the plastic sector is the lack of an institutional arrangement dedicated to this sector, in order to provide supporting services such as skilled manpower, testing facilities for quality control, innovative technology and consultancy services. The availability of cheap labor and the fast developing plastic wastes recycling industry due to rising cost of petroleum (raw material of polymers) provide Bangladesh potential advantage of competitiveness in the global market.

An expert (BUET, BCSIR, BITAC, BPGMEA) consultation meeting held on the plastic sector organized by the SME Foundation in 2008, has recommended setting up Bangladesh Institute of Plastic Engineering and Technology (BIPET). Aims and activities of this institute are given in this paper. This proposal is in the light of Indian experience. The entrepreneurs in the plastic sector have developed the plastic industries with their own initiative and finance. Now, considering huge potential of this sector and the multi-dimensional nature of the constraints, the government must provide supportive policy and institutional arrangements.
\end{abstract}

\subsection{EMERGENCE OF PLASTIC INDUSTRIES}

The plastic industry in Bangladesh is relatively new compared with the textile and leather industries. The plastic industry began its journey as a small industry in 1960 's. Some of the milestones of the development of plastic industries are listed in Table-1.

Since early 1990's the plastic industry witnessed rapid growth due to introduction of free market economy.

\subsection{SALIENT FEATURES OF PLASTIC INDUSTRIES}

The plastic industry in Bangladesh uses imported polymer granules. During the period 1989 to 2007, the import of polymers increased from 10,000 tonnes to 289,000 tonnes per year. At present total consumption of polymers including imported polymers and recycled plastic wastes is 750,000 tonnes in FY 20102011. This corresponds to the per capita consumption of plastics in Bangladesh 5 $\mathrm{kg}$ per year against the world average 30 $\mathrm{kg}$. Per capita consumption in India and ASEAN countries are $8 \mathrm{~kg}$ and $17 \mathrm{~kg}$ respectively.

E-mail: seraj@che.buet.ac.bd 
Table1: Milestones of Development of Plastic Industries in Bangladesh

\begin{tabular}{|l|l|}
\hline Year & Technology and Products \\
\hline 1960 's & $\begin{array}{l}\text { Small products such as } \\
\text { toys, bangles and photo } \\
\text { frame were made using } \\
\text { hand made molds. Plastic } \\
\text { spare parts for jute mills. }\end{array}$ \\
\hline 1970 's & $\begin{array}{l}\text { Automatic machines were } \\
\text { installed to manufacture } \\
\text { household utensils such as } \\
\text { plastic jugs and plate }\end{array}$ \\
\hline 1980 's & $\begin{array}{l}\text { Film blowing machines to } \\
\text { manufacture plastic bags }\end{array}$ \\
\hline 1991 & $\begin{array}{l}\text { Plastic accessories } \\
\text { especially hangers for } \\
\text { exportable garments }\end{array}$ \\
\hline 2000 's & $\begin{array}{l}\text { Molded plastic chairs and } \\
\text { tables. Water tank made by } \\
\text { rotation molding. Locally } \\
\text { developed machines } \\
\text { (shredder, extruder, } \\
\text { pelletizer) for recycling } \\
\text { plastic wastes. }\end{array}$ \\
\hline
\end{tabular}

At present plastic consumption is a measure of per capita GDP in a country, Figure 1. From this figure it can be seen that per capita consumption of plastics in Bangladesh lags behind China and India.

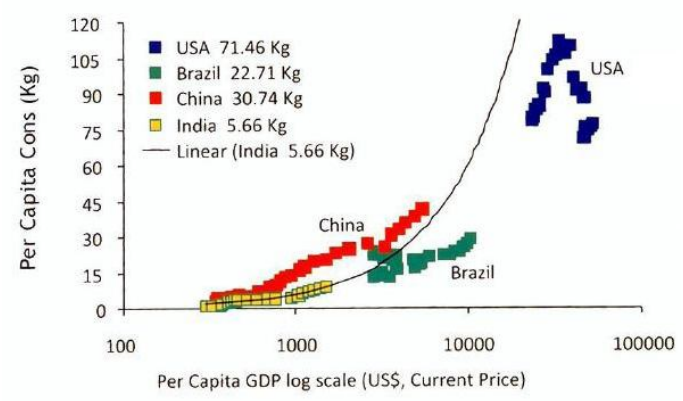

Figure 1: Per capita polymer consumption vs. per capita GDP of selected countries (2009) (Ref. Chemical and Petro-chemical Manufacturers' Association, India)
There are about 3000 manufacturing units in the plastic sector of which $98 \%$ belongs to the Small and Medium Enterprises (SMEs). The plastic sector contributes 1.0 percent of GDP and provides employment for half a million people. Additional information on the plastic sector can be seen from Table- 2 .

Table 2: Bangladesh Plastic Sector at a Glance

\begin{tabular}{|l|l|}
\hline Domestic Market & $\begin{array}{l}\text { Tk. 7,000 Crore (US } \\
\$ 950 \text { million) }\end{array}$ \\
\hline $\begin{array}{l}\text { Per Capita } \\
\text { Plastic } \\
\text { Consumption }\end{array}$ & About 5 kg/Year \\
\hline $\begin{array}{l}\text { Direct Export } \\
\text { Earning }\end{array}$ & $\begin{array}{l}\text { Tk. 500 Crore (US \$ } \\
69 \text { million) }\end{array}$ \\
\hline $\begin{array}{l}\text { Deem Export: } \\
\text { RMG } \\
\text { Accessories }\end{array}$ & $\begin{array}{l}\text { Tk. 2000 Crore (US } \\
\text { \$286 million) }\end{array}$ \\
\hline $\begin{array}{l}\text { Manufacturing } \\
\text { Units }\end{array}$ & $\begin{array}{l}\text { About 3,000 small, } \\
\text { medium and large } \\
\text { plastic manufacturing } \\
\text { units operate across } \\
\text { the country }\end{array}$ \\
\hline Recycling Sector & $\begin{array}{l}\text { There are 300 small } \\
\text { units in Dhaka City } \\
\text { which recycle about } \\
138 \text { tonnes/day }\end{array}$ \\
\hline Growth & $\begin{array}{l}\text { 20 percent per annum } \\
\text { during the 1990's }\end{array}$ \\
\hline Employment & $\begin{array}{l}\text { Half a million workers } \\
\text { are employed in the } \\
\text { sector }\end{array}$ \\
\hline
\end{tabular}

Source: UN-ESCAP Report-2009

(Updated)

Plastic Products: Some of the products for local consumption and export are given in Table-3. Applications of plastic products include Packaging, Healthcare/Pharmaceutical, Construction, Consumer Products, Agriculture and other Industrial uses. 
Table 3: Plastic Products and its Applications in Bangladesh

\begin{tabular}{|l|l|}
\hline APPLICATIONS & PRODUCTS \\
\hline $\begin{array}{l}\text { Accessories for } \\
\text { RMG }\end{array}$ & $\begin{array}{l}\text { Packaging material, } \\
\text { bags, hanger etc. }\end{array}$ \\
\hline $\begin{array}{l}\text { Household, } \\
\text { Tableware } \\
\text { Kitchenware }\end{array}$ & $\begin{array}{l}\text { Bucket, jug, plate, } \\
\text { glass, containers etc. }\end{array}$ \\
\hline Furniture ware & Chair, Table etc. \\
\hline Packaging & $\begin{array}{l}\text { All kinds of food } \\
\text { and non-food } \\
\text { packaging }\end{array}$ \\
\hline Healthcare & $\begin{array}{l}\text { Toiletries (Soap } \\
\text { case, tooth brush), } \\
\text { Medical Accessories } \\
\text { (blood bag, saline } \\
\text { bag, injection, } \\
\text { medicine container) }\end{array}$ \\
\hline $\begin{array}{l}\text { Building and } \\
\text { construction }\end{array}$ & $\begin{array}{l}\text { Plastic pipe, door, } \\
\text { toilet flush etc. }\end{array}$ \\
\hline $\begin{array}{l}\text { Electrical and } \\
\text { Electronic } \\
\text { Equipment }\end{array}$ & $\begin{array}{l}\text { Electrical cables and } \\
\text { wires, switches, } \\
\text { regulator, computer } \\
\text { accessories, } \\
\text { telecommunication } \\
\text { equipment etc. }\end{array}$ \\
\hline $\begin{array}{l}\text { Industrial } \\
\text { Applications }\end{array}$ & $\begin{array}{l}\text { Plastic pipes for } \\
\text { irrigation, } \\
\text { plastic films for } \\
\text { shedding crops }\end{array}$ \\
Eroducts
\end{tabular}

\subsection{PROSPECTS OF PLASTIC INDUSTRIES}

Shift of Manufacturing Industries: Manufacturing is a sun set industry in the west. Plastic consumption there is the highest on a per capita basis. A shift in manufacturing from the west to a region with low labor cost, high knowledge and technology base can be expected (Ambani1998). Bangladesh has a competitive advantage in the case of labor cost. Other qualities are to be acquired in order to be competitive in the international market.
Export Earnings: Bangladesh is making an effort to diversify its expert items. Among the many items of export RMG, knitwear, frozen food, jute and leather constitute the major export of over $85 \%$ (Table- 4). Export of plastic goods in 2009-2010 was about US \$ 337 million. It includes both direct export and deem (RMG accessories) export. Table-5 indicates that the direct export of plastic goods has been on the increase every year. In 2010-2012 the target is US \$ 84 million.

Raw Materials: There is no production of polymers in Bangladesh. The plastic industry uses imported raw materials of polymer granules. However, this not a disadvantage.

Competitiveness: The availability of cheap labor and the fast developing recycling industry of postconsumer plastic wastes in Bangladesh are potential advantages to provide competitiveness in the global market (Katalyst-2005).

Table 4: Sectorwise export earnings of Bangladesh in 2009-2010.

\begin{tabular}{|c|c|c|}
\hline Sector & $\begin{array}{l}\text { Export in } \\
\text { Million } \\
\text { US \$ }\end{array}$ & $\begin{array}{l}\text { Sectoral } \\
\text { Share } \\
(\%)\end{array}$ \\
\hline RMG \& Knitwear & $12,496.72$ & 77.12 \\
\hline Jute \& Jute Goods & 736.44 & 4.54 \\
\hline Tea & 5.65 & 0.03 \\
\hline $\begin{array}{l}\text { Leather \& } \\
\text { Footwear }\end{array}$ & 434.61 & 2.68 \\
\hline Frozen Foods & 437.40 & 2.70 \\
\hline $\begin{array}{l}\text { Agricultural } \\
\text { Products }\end{array}$ & 242.35 & 1.50 \\
\hline $\begin{array}{l}\text { Engineering } \\
\text { Products }\end{array}$ & 311.09 & 1.92 \\
\hline Plastic Goods & 336.60 & 2.08 \\
\hline Ceramic Products & 30.78 & 0.19 \\
\hline Others & $1,173.01$ & 7.24 \\
\hline Total export & $16,204.65$ & 100.00 \\
\hline
\end{tabular}


Table 5: Direct Export of Plastic Goods

\begin{tabular}{|l|r|r|}
\hline Financial Year & \multicolumn{1}{|l|}{$\begin{array}{l}\text { Million } \\
\text { US \$ }\end{array}$} & $\begin{array}{l}\text { Growth Rate } \\
(\%)\end{array}$ \\
\hline $2003-2004$ & 22.0 & 76.4 \\
\hline $2004-2005$ & 38.8 & 14.0 \\
\hline $2005-2006$ & 44.4 & 7.5 \\
\hline $2006-2007$ & 48.0 & 12.7 \\
\hline $2007-2008$ & 54.1 & -3.0 \\
\hline $2008-2009$ & 52.3 & -3.0 \\
\hline $2009-2010$ & 50.6 & 35.0 \\
\hline $2010-2011$ & 68.7 & 22.0 \\
\hline $2011-2012$ & $\begin{array}{r}84.2 \\
\text { (Target) }\end{array}$ & \\
\hline
\end{tabular}

Average $20.2 \%$

Source: Export Promotion Bureau

(Prothom Alo, October 15, 2011)

Market Size Potential: If we look back, in 1990 the consumption of plastics in Bangladesh was 15,000 tonnes. It took 20 years to reach the 750,000 tonnes, an increase of 50 times. At present the per capita consumption of plastics in Bangladesh is $5 \mathrm{~kg} /$ year as compared to world average of $20 \mathrm{~kg}$. Thus, there is a huge potential for the growth of plastic industry in the country.

\subsection{CHALLENCES}

First and foremost challenge for the plastic industry in Bangladesh is to be competitive in the global market. Some of the large-scale plastic industries have demonstrated a capability to be world class in terms of technology, quality and costs.

However, there are 3000 plastic manufacturing units of which $98 \%$ belong to the small-medium sector (SMEs). The major challenge facing this sector is to make the SMEs competitive in the global market by upgrading them in terms of innovative technology, products diversity and operation costs. It is to be emphasized that technology is changing rapidly and the life cycle is short.
Recognizing this reality, the SME foundation organized a day-long Expert Consultation Meeting on "Technology Development, Acquisition and Transfer in Plastic Subsector" along with other five sub-sectors on April 24, 2008. The meeting on plastic subsector was attended by experts from BUET, BCSIR, BITAC and BPGMEA (Bangladesh Plastic Goods Manufactures and Exporters Association). The author was the keynote speaker. The following paragraphs describe the constraints and recommendations.

Constraints: Major constraints are the lack of institutional arrangement dedicated to the plastic sector. As a result there is no supporting service available for the following.

- Skilled manpower development

- Mold design mold making

- Testing facilities for quality control services

- Technical consultancy services

- Trouble shooting in operation of processing machine

- Proper management of plastic wastes

- Negative environmental image of plastic industries

For an environmentally sustainable growth of the plastic sector the above mentioned constraints need government policy support and intervention by the SME Foundation. The Environmental issue related to the plastic industries is discussed briefly.

\section{Environmental Issue and Recycling of} Plastic Wastes:

Plastic products manufacturing is relatively environmentally sound. During manufacturing process the rejects and machine spares are usually recycled in the factory premises. Use of plastic chair, table and door save the forests with positive impact on the environment. 
However, management of postconsumer plastic wastes is a challenging problem in every country.

The plastic waste management of thin polyethylene (PE) bags has been a serious environmental problem in Bangladesh during the past decade. In the late 1990's the littering of thin polyethylene bags had created such an unmanageable situation throughout the country that in April 2002 the parliament passed a bill banning the thin plastic bags.

More than eight years has passed since the passing of the bill, the problem has not yet been fully solved. Lack of proper management of thin plastic bags is one of the reasons for the existing negative image of the plastic industry in the country. This affects export of plastic goods due to noncompliance of environmental standards by the plastic sector. The entrepreneurs in the plastic sector and the policy makers must create public awareness and provide alternative to plastic shopping bags.

\subsection{RECOMMENDATIONS FOR CAPACITY BUILDING}

A critical analysis of issues and policy related to the plastic sector revealed that the absence of an institutional arrangement is the main obstacle to the technological capacity building for self-reliance. Major areas of promotional activities by the SME Foundation in short, medium and longterms should include the following.

\begin{tabular}{|c|c|}
\hline $\begin{array}{l}\text { SHORT } \\
\text { TERM }\end{array}$ & 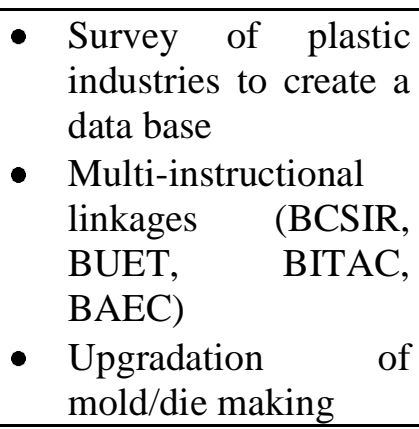 \\
\hline
\end{tabular}

\begin{tabular}{|c|c|}
\hline & $\begin{array}{l}\text { Quality control } \\
\text { services } \\
\text { - Training of technical } \\
\text { manpower } \\
\text { - Upgradation of } \\
\text { technology in } \\
\text { recycling factories }\end{array}$ \\
\hline $\begin{array}{l}\text { MEDIUM } \\
\text { TERM }\end{array}$ & $\begin{array}{l}\text { - Access to APCTT } \\
\text { networking through } \\
\text { the proposed NTTC } \\
\text { - Relocation of plastic } \\
\text { recycling factories } \\
\text { from old Dhaka to } \\
\text { outside Dhaka }\end{array}$ \\
\hline $\begin{array}{l}\text { LONG } \\
\text { TERM }\end{array}$ & $\begin{array}{llr}\text { Setup Bangladesh } \\
\text { Institute of Plastic } \\
\text { Engineering and } \\
\text { Technology (BIPET) }\end{array}$ \\
\hline
\end{tabular}

APCTT: Asian Pacific Centre for Transfer of Technology

NTTC: National Technology Transfer Centre (Proposed)

BITAC: The Plastic Division in BITAC was established with UN assistance in early 1980's. This division lags well behind the current needs of plastic industries in Bangladesh. However, mold making experience of BITAC may be useful to upgrade this technology.

The APCTT-NTTC linkage would be a first step towards technology transfer. This linkage has a limitation because the APCTT is a facilitating institution of the UN-ESCAP. It should be emphasized that each country has to acquire technological capability through its national institutional. In the long-term, therefore, it is proposed to set up a specialized plastic institute entitled "Bangladesh Institute of Plastic Engineering and Technology (BIPET)". This will enhance the technological capability of the plastic sector to face the challenges of the highly competitive global 
market. Aims and areas of activities of proposed institute are given below.

\subsection{AIMS AND AREAS OF ACTIVITIES OF BIPET}

The aims of BIPET are to conduct research and develop system for optimal processing of polymers including plastic postconsumer wastes. The institution will act as a storehouse of information on technology transfer and provide training and consultancy services to the plastic industry.

\section{Areas of Activities:}

$>$ Academic affairs for manpower development and training

$>$ Research \& Development

$>$ Mold/die manufacturing

$>$ CAD Services

$>$ Testing and Consultancy Services

$>$ Technology Upgrading program

$>$ Plastics and environment for sustainable development

\subsection{CONCLUSSIONS}

The plastic sector has opened a new era of manufacturing plastic goods which have an excellent export potential. Since most of the plastic industries are in the small and medium categories, the SME Foundation extending due support to this sector can improve its competitiveness in the global market.

The negative image of the plastic sector in Bangladesh can be changed through proper management of plastic wastes.

Establishment of a Plastic Institute and strengthening of Plastic Foundation are appropriate institutional arrangements for sustainable development of the plastic industries.

\section{ACKNOWLEDGEMENT}

The author wishes to acknowledge with thanks the helpful suggestions received from the experts of different Institutions/Associations (BCSIR, BUET, BITAC and BPGMEA) during expert consultation meeting on "Technology Development, Acquisition and Transfer in Plastic Subsector" organized by the SME Foundation on April 24, 2008.

\section{REFERENCES}

1. Ambani, M. (1998). A vision for the Indian Plastic Industry in the new millennium, Plastindia Foundation Meeting, Mumbai.

2. Islam, M.S. (2005), "Plastic Waste Management", Souvenir of International Plastic Fair, Bangladesh Plastic Goods and Manufactures Association (BPGMEA), Dhaka.

3. Islam, M.S. (2008). "Expert Consultation Meeting on Technology Development, Acquisition and Transfer: Plastic Subsector", Organized by the SME Foundation, Bangladesh.

4. Islam, M.S. (2010). "Role of the SME Foundation in Technological Capacity Building of Plastic Subsector", Souvenir of International Plastic Fair, BPGMEA, Bangladesh.

5. Jahan, S.M. and Khan, M.S.N. (2009), "Achieving Global Value Chain Competitiveness - A strategic Analysis of the plastic sector of Bangladesh", Commissioned by UN-ESCAP.

6. Kapur, G. S. and Shashikant (2011), Indian Polymer Industry.

7. Karmoker, S. (2011), "Bangladesh Towards Self-reliance in Plastic Goods", Prothom Alo.

8. KATALYST-Bangladesh (2005). Market Brief: PLASTICS. 